\title{
BCL2 Gene Mutation
}

National Cancer Institute

\section{Source}

National Cancer Institute. BCL2 Gene Mutation. NCI Thesaurus. Code C158490.

A change in the nucleotide sequence of the $\mathrm{BCL} 2$ gene. 